\title{
The Endangered Ganges River dolphin Platanista gangetica gangetica in Nepal: abundance, habitat and conservation threats
}

\author{
Shambhu Paudel ${ }^{1,2, *}$, Prabhat Pal ${ }^{2}$, Michael V. Cove ${ }^{3}$, Shant Raj Jnawali ${ }^{4}$, \\ Grant Abel $^{5}$, John L. Koprowski ${ }^{6}$, Rishi Ranabhat ${ }^{7}$ \\ ${ }^{1}$ Kathmandu Forestry College, PO Box 8973, Kathmandu, Nepal \\ ${ }^{2}$ The Himalaya, Kathmandu, Nepal \\ ${ }^{3}$ Department of Applied Ecology, North Carolina State University, Raleigh, North Carolina 27695, USA \\ ${ }^{4}$ Hariyo Ban Program, World Wildlife Fund (WWF-Nepal), Kathmandu, Nepal \\ ${ }^{5}$ Ocean Park Corporation, Hong Kong \\ ${ }^{6}$ Wildlife and Fisheries Science, School of Natural Resources and the Environment, University of Arizona, Tucson, \\ Arizona 85721, USA \\ ${ }^{7}$ Department of National Parks and Wildlife Conservation, Kathmandu, Nepal
}

\begin{abstract}
Conservation of the last remaining Ganges River dolphins Platanista gangetica gangetica in Nepal will require robust population estimates and better information on suitable habitat characteristics. To gain a better understanding of these parameters, we conducted boatbased surveys in the 3 major river systems (Karnali, Sapta Koshi, and Narayani) of Nepal. We recorded covariates at high spatial resolution and utilized these data to inform occurrence and abundance models. We allowed for detection bias by applying occupancy and N-mixture models that account for imperfect and heterogeneous detection. Occupancy results indicate that dolphin site use varies among the different river systems, across 2 seasons, and increases with river depth. River effects received nearly $100 \%$ of the model support and had the strongest influence on dolphin occurrence and abundance. The seasonal influence on dolphin occurrence in the systems $\left(\Sigma \omega_{i}=0.997\right)$ revealed that occupancy probabilities were heightened during the pre-monsoon season. Deep pool habitat was also identified as a predictor of dolphin habitat use, which accounted for $41.02 \%$ of all dolphin sightings occurring in this habitat. Although estimates vary depending on season, we estimate that there are between 37 and 42 (95\% CI: 28 to 52) Ganges River dolphins distributed in the rivers of Nepal. Results suggest that seasonality and each specific river affect dolphins and their habitat in Nepal; we strongly recommend site and season-specific conservation actions. Further research on the integration of additional and alternative abundance techniques, behavioral studies, and pursuit of a conservation genetics approach are all important steps in the management of this endangered species.
\end{abstract}

KEY WORDS: Ganges River dolphin - Endangered species - Abundance · Habitat - Distribution · Nepal

\section{INTRODUCTION}

The Ganges River dolphin (GRD) Platanista gangetica gangetica is one of the most threatened freshwater dolphins in the world. It is native to the major lowland rivers and tributaries of Nepal, India, and Bangladesh

${ }^{*}$ Corresponding author: oasis.excurrent@gmail.com
(Shostell \& García 2010). This subspecies has been categorized as Endangered by the IUCN since 2004; however, a panel of experts registered the dolphin as Critically Endangered (locally) due to significant declines in population and range (Janawali \& Bhuju 2000), with an estimated population of fewer than 20

(C) The authors 2015. Open Access under Creative Commons by Attribution Licence. Use, distribution and reproduction are unrestricted. Authors and original publication must be credited. 
adults in Nepal (Jnawali et al. 2011). Anthropogenic activities, including development, fishing and alteration of natural water flow processes have all been implicated in the apparent decline in abundance (Smith et al. 1994, WWF-Nepal 2006). Perhaps the greatest threat to dolphin persistence is the segregation of the entire population into small sub-populations separated by structures including dams and dikes (e.g. barrages), in which only limited migration is likely possible during the monsoon period (Smith 1993).

Despite some notable actions by independent conservation leaders, the river dolphin has received less attention than other charismatic megafauna of Nepal. Past efforts to monitor the species have primarily involved boat-based counts of individuals, which were used to estimate historical encounter rates and abundances (Shrestha 1989, Smith 1993, WWFNepal 2006, Chaudhary 2007, Kelkar et al. 2010). The general trend across all areas is that these small, isolated populations have declined (Smith 1993, WWF-Nepal 2006, Wakid 2007, Khatri et al. 2010), some at alarming rates (e.g. $26 \%$ over $12 \mathrm{yr}$ in parts of the Brahmaputra; Wakid 2007). Sparse sightings of 1 or 2 individuals indicate that suitable hydro-physical habitat is rare in the river systems of Nepal (Smith 1993, Paudel 2012).

While protected areas overlap with the dolphin's distribution in Nepal (e.g. Bardia National Park, Koshi Tappu Wildlife Reserve, and Chitwan National Park), their numbers and distribution have still declined significantly since monitoring began (Shrestha 1989, Smith 1993, Smith et al. 2006, WWF-Nepal 2006), with the species vanishing completely from some rivers (i.e. present in 4 rivers in the 1980s, now found only in 3; Leatherwood \& Reeves 1994). Because of the critical status of this group of GRDs, it was suggested that regular monitoring be undertaken (Leatherwood \& Reeves 1994). Here, we provide detailed population estimates and describe the ecological factors associated with their occurrence in 3 river systems in Nepal where the dolphins have been documented. This is the first attempt in Nepal to obtain detailed estimates of dolphin abundance and habitat characteristics, accounting for detection bias during 2 critical seasons (pre- and post-monsoon) in 3 major rivers.

\section{MATERIALS AND METHODS}

\section{Study area}

We conducted surveys on the 3 largest river basins in Nepal where the river dolphins have been histori- cally documented: the Karnali $\left(28.630329^{\circ}\right.$ N, 81.274 $\left.830^{\circ} \mathrm{E}\right)$, Sapta Koshi $\left(26.722925^{\circ} \mathrm{N}, 87.083357^{\circ} \mathrm{E}\right)$ and Narayani $\left(27.563377^{\circ} \mathrm{N}, 84.064135^{\circ} \mathrm{E}\right)$ (Fig. 1). The Government of Nepal, Department of National Parks and Wildlife Conservation, Kathmandu granted permission for this project along these 3 river systems. All of these rivers are located downstream of the Siwalik foothills of the Nepalese Himalayas. This study area represents the extreme upstream limit of GRD distribution in southern Asia. With headwaters in the southern slopes of the Himalayas of Tibet, seasonal melting of snow results in fluctuating water levels in these river systems. The surveyed areas along the rivers consisted of $42 \mathrm{~km}$ along the Karnali from the Karnali bridge to the Nepal/India border; $36 \mathrm{~km}$ along the Sapta Koshi from the Srilanka Tappu to the Nepal/India border; and $37 \mathrm{~km}$ along the Narayani from the Amaltari post to Treveni Ghat. Surveys were restricted to Nepal (in all river systems) due to security concerns in India. All 3 river basins are characterized by relatively high velocity flows in comparison to downstream waters, large seasonal and year-to-year variations in stream flow and sediment transport with mixed-use riparian areas. Most of the local people living close to the river systems are illiterate, with agriculture and fishing as their major occupations. Hence, immense pressure from the local people has increased the spatial overlap between dolphins and fisheries in the river systems.

These river systems are all large tributaries of the Ganges River in India, where relatively high numbers of GRDs have been reported. The rivers are affected by the barrages at the Nepal-India border (Narayani) or just above (Sapta Koshi: $7 \mathrm{~km}$ north of border) or below the border (Karnali: $20 \mathrm{~km}$ south of border), which are used to divert water for irrigation and to control flooding in India. Upstream dolphins may move downstream through the barrages during flood periods, potentially resulting in permanent loss of individuals from Nepal.

\section{Dolphin surveys}

Surveys occurred during low water seasons (premonsoon: March to May 2013 and post-monsoon: November to January 2014). During each season, we surveyed all 3 rivers on 3 separate occasions with an interval of 2 wk between surveys. We only sampled during clear weather conditions, and all surveys were completed over the course of $1 \mathrm{~d}$. We considered dolphins within a distance of $200 \mathrm{~m}$ from each other to be a single group. We followed the survey 


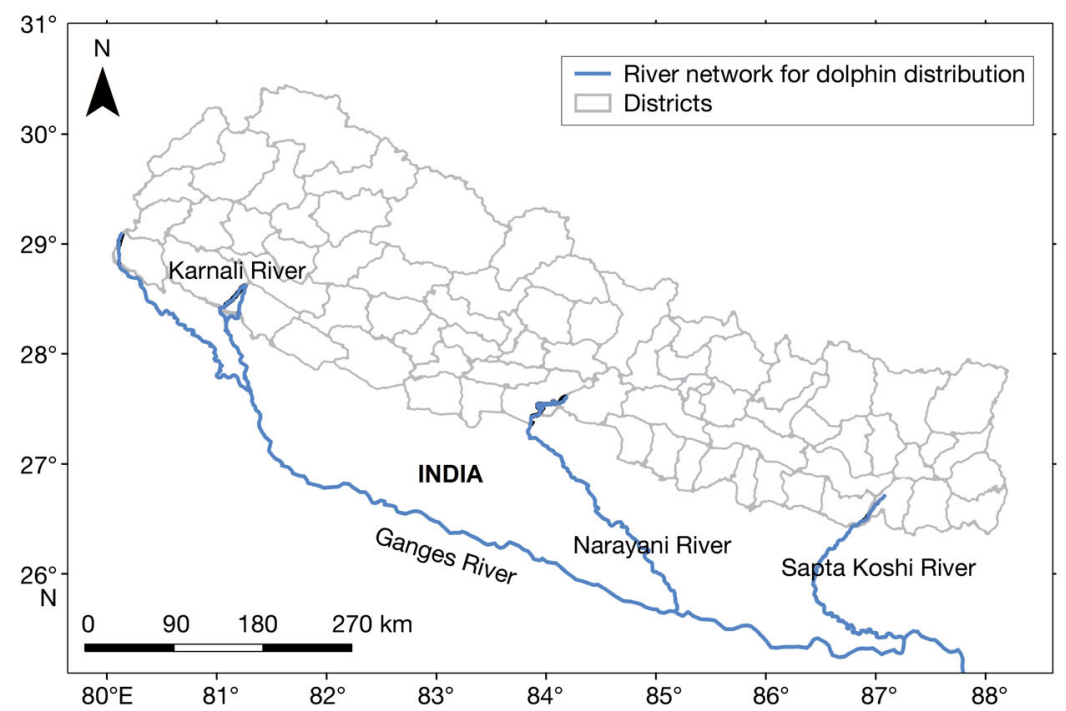

Fig. 1. The 3 surveyed rivers and their location within the Ganges River watershed and the protected areas they traversein Nepal

the boat remained midway between the banks in order to standardize these values. We classified habitat as either meandering $(\mathrm{M})$, river confluence $(\mathrm{CF})$, deep pool $\left(\mathrm{DP}_{i}>3 \mathrm{~m}\right.$ in depth) or straight channel $\left(\mathrm{SC}_{i}<3 \mathrm{~m}\right.$ in depth), following previous guidelines (Biswas \& Boruah 2000). We compared mean depths and widths between seasons and among rivers and habitat types using $t$-tests (seasonal) and ANOVA and Tukey's HSD post hoc test (habitats and rivers), with a significance level of $\alpha=0.05$.

\section{Habitat occupancy model}

From the survey data, we formulated binomial detection histories of dolphin detections and non-detec-

methods recommended by Smith \& Reeves (2000b) for narrow channel habitat. It was assumed that allowing a dolphin to surface at least once within our range of detection would avoid double counting, which was achieved by maintaining a boat speed of $5 \mathrm{~km} \mathrm{~h}^{-1}$ (Kelkar et al. 2010, Richman et al. 2014). Teams typically consisted of 6 individuals, representing researchers, park officials and NGO members on a single platform (eye height $1.5 \mathrm{~m}$ ), with 2 primary observers and 1 rear observer. Surveys began at 09:00 $\mathrm{h}$ and ended at 16:00 $\mathrm{h}$ during clear weather conditions. The 2 primary members were positioned at the front of the vessel, left and right of a data recorder, and continually searched for dolphins using binoculars and occasionally with unaided eyes. Individual dolphins were classified as newly born, juvenile or adult based on size and color. The data recorder documented sighting time, position (latitude and longitude), observer number, group size, distance from the dolphin to the nearest river bank, and a code for habitat type. Positions were rotated to minimize perception bias at an interval of $2 \mathrm{~h}$. The single rear observer was responsible for counting individuals (if any) missed by primary observers.

During surveys, we also collected habitat data along $300 \mathrm{~m}$ river segments that we considered to be the sites of the subsequent occupancy analysis. Habitat characteristics included measures of water depth using a depth finder (Leatherwood et al. 2000, Akbar et al. 2004, Smith et al. 2008), river width using a range finder (Smith et al. 2006, 2008) and habitat structure of the river. While measuring river depth, tions for integration into occupancy models (Mackenzie et al. 2002). Occupancy models are hierarchical, and estimate species occurrence or site use $(\psi)$ while also estimating a detection nuisance parameter $(p)$ (Royle \& Dorazio 2008). This class of models is useful because it allows us to estimate occurrence (site use) probabilities as a function of habitat covariates via the logit-link. Detection histories were based on the 3 separate survey occasions for each river (e.g. history 101 = detected on first survey, not detected on second survey, detected on third survey). Since there were $2 \mathrm{wk}$ between each survey, and the sites (300 m river segments) in the analysis were relatively small in comparison to individual dolphin movements, we considered $\psi$ to represent dolphin site use. We first modeled detection as either a function of time (such that each survey had a different probability of detecting dolphins), as a function of season, river depth, river width, an additive model with both depth and width, or as constant across all surveys (6 detection models while keeping $\psi$ constant, similar to Cove et al. 2014). We then selected the top-ranking detection covariates and included those in all further occupancy models assessing site use. Although detection could also be affected by other covariates, we did not consider any additional effects because sampling only occurred during favorable weather/visibility. Based on current ecological knowledge of GRDs, we formulated 14 a priori hypotheses of dolphin site use based on habitat, season, river, and depth and width profiles (see Table 1). We also included a constant model in which all sites had equal use probabilities, 
and a global model which included additive effects of all covariates. We executed the occupancy models using the freely available software PRESENCE v.8.0 (Hines 2012). For model selection, we adopted the information-theoretic approach and ranked each hypothesis based on its relative Akaike information criterion (AIC) and the information distance to the top model in the set (Burnham \& Anderson 2002). Furthermore, we calculated the cumulative Akaike weight $\left(\Sigma \omega_{i}\right)$ of model support for each covariate to determine its relative importance to other covariates, with higher weight suggesting more influence (Burnham \& Anderson 2002).

\section{Dolphin abundance model}

To estimate global abundance, we utilized $N$-mixture models, which are explicit process hierarchical models that account for imperfect and heterogeneous detection (Royle \& Dorazio 2008). Each river was broken down into what we considered independent segments, which were often separated by a barrage or other structure preventing migration. There were a total of 8 river segments of variable length among the 3 rivers (3 in Karnali, 3 in Sapta Koshi, and 2 in Narayani). We modeled the detection parameters as constant over time since the surveys were only conducted on optimal visibility days and we did not consider there to be any detection concerns at the scale of the $N$-mixture model sites based on relatively high detection probabilities from the site-use models (see 'Results'). We analyzed dolphin abundance in these segments as being independent between seasons (16 sites in the model) since the monsoon season connects them with flash floods, allows some migration and alters the rivers' physical attributes. We first modeled the abundance with a Poisson distribution and then a negative binomial distribution to account for over-dispersion. We compared multiple a priori models in which we modeled GRD abundance as a function of river, habitat, season, constant and additive variations of those covariates (see Table 3). We then utilized the most supported model distribution for the covariate models using function 'pcount' in library 'unmarked' (Fiske \& Chandler 2011), within the computational software R v.3.0.2 (R Development Core Team 2013). To determine covariate effects, the logit-link informs the detection component of the model (as in occupancy models), while the log-link function informs the abundance component. We compared the candidate models via a model selection approach similar to the occupancy analyses, using AIC and Akaike weights (Akaike 1973). We estimated mean abundance estimates and standard errors through back-transformation of values given by the most supported model and the most supported constantmodel for comparison to observed counts.

\section{RESULTS}

\section{Depth, width and dolphin habitat characteristics of river systems}

The mean $( \pm \mathrm{SD})$ depth and width of the rivers differed between the post-monsoon (width: $236.53 \pm$ $121.67 \mathrm{~m}$; depth: $1.60 \pm 1.24 \mathrm{~m}$ ) and pre-monsoon seasons (width: $251.97 \pm 119.03 \mathrm{~m}$; depth: $3.55 \pm$ $3.50 \mathrm{~m}$ ): width: $t=-2.798$, df $=1004.47, \mathrm{p}=0.005$; depth: $t=-13.51, \mathrm{df}=650.85, \mathrm{p}<0.001$. Similarly, the mean depth and width of the river sections measured at $300 \mathrm{~m}$ intervals differed between river systems (width: $F=81.834$, df = 2, p < 0.001, Karnali: $187.16 \pm$ 78.55 m, Sapta Koshi: $258.04 \pm 132.59$ m, Narayani: $197.11 \pm 56.36 \mathrm{~m}$; depth: $F=712.209, \mathrm{df}=2, \mathrm{p}<0.001$, Karnali: $5.55 \pm 4.13 \mathrm{~m}$, Sapta Koshi: $1.40 \pm 1.10 \mathrm{~m}$, Narayani: $2.65 \pm 1.56 \mathrm{~m})$. Mean depth varied between all pairs of river systems (Tukey's test, p < 0.001 for all pairs) but the mean width between Narayani and Karnali was not different (Tukey's test, $\mathrm{p}=0.267$ ). Mean width (DP: $231.88 \pm 99.52 \mathrm{~m}$; SC: $220.50 \pm 99.42 \mathrm{~m} ; \mathrm{CF}: 266.41 \pm 142.04 \mathrm{~m}$; M: $247.06 \pm$ $131.11 \mathrm{~m}$ ) and depth (DP: $4.60 \pm 2.92 \mathrm{~m}$; SC: $1.59 \pm$ $0.98 \mathrm{~m} ; \mathrm{CF}: 2.94 \pm 3.26 \mathrm{~m} ; \mathrm{M}: 1.27 \pm 1.06 \mathrm{~m}$ ) differed among habitat types for all river systems (width: $F=$ 10.38, df = 3, p < 0.001; depth: $F=463.18$, df $=3$, p < 0.001). Mean depth and width differed between all pairs of habitat types ( $p<0.001$ for all pairs) except for width between DP and SC ( $p=0.128)$. There was a significant interaction between the effects of river systems and season on the depth of river systems (univariate test, $F=77.37, \mathrm{df}=2, \mathrm{p}<0.001$ ) but not for width of river by the same interaction effects $(F=$ 1.472, df $=2, \mathrm{p}=0.230$ ).

\section{Occupancy and abundance}

The additive detection model with river width and depth received the most model support, so we included those positive detection covariates in all further site-use models (Table 1$)$. The mean $( \pm \mathrm{SE})$ probability of detecting dolphins for each independent survey was $0.563 \pm 0.045$. Of the 14 a priori models 
that we compared to predict river dolphin site use, only 2 models received nearly all of the model support $\left(\Sigma \omega_{i}=0.997\right.$; Table 1$)$. River effects received $100 \%$ of the model support and had the most influence on dolphin occurrence. The 3 rivers had different occurrence probabilities; both Karnali and Sapta Koshi were similar and significantly more likely to be used by river dolphins than the baseline Narayani River (Table 2). Models incorporating a seasonal influence on dolphin site use in the river systems $\left(\Sigma \omega_{i}\right.$ $=0.997$; Table 1) increased occupancy probabilities during the pre-monsoon season (Table 2). All other covariates that we examined received support from the global model, each with $\Sigma \omega_{i}=0.332$ (Tables 1 \& 2 ). The deep pool habitat was the only significant predictor (CI excluded 0) of dolphin site use from the remaining covariates (Table 2$)$. Mean $( \pm \mathrm{SD})$ depth and width of the dolphin sighting locations was 4.24 \pm 1.98 and $225.93 \pm 96.63 \mathrm{~m}$, respectively. The greatest proportion (41.02\%) of sightings occurred in deep pool habitat, followed by confluence (28.20\%) and meandering $(12.82 \%)$.

We initially examined the Poisson and negative binomial distributions for river dolphin abundance. The negative binomial distribution received more support and was used for further mixture models to predict the abundance of dolphins. Similar to the occurrence models, only 2 of the $N$-mixture models received the majority of the model support $\left(\Sigma \omega_{i}=0.998 ;\right.$ Table 3$)$. The different river systems once again had different effects on dolphin abun-

Table 1. Model selection statistics for all occurrence models, as well as initial detection models with constant $\psi$, for the Ganges River dolphin Platanista gangetica gangetica derived from survey data from the Karnali, Sapta Koshi and Narayani Rivers, Nepal. AIC: Akaike's information criterion; $\triangle$ AIC: AIC information difference, $\omega_{i}$ : Akaike weight; $K$ : no. of model parameters; $p$ : detection nuisance parameter

\begin{tabular}{|c|c|c|c|c|c|}
\hline Model & AIC & $\Delta \mathrm{AIC}$ & $\omega_{i}$ & $K$ & $\begin{array}{c}\text {-2log- } \\
\text { likelihood }\end{array}$ \\
\hline$\psi($ river + season $), p($ width + depth $)$ & 514.12 & 0 & 0.665 & 7 & 500.12 \\
\hline$\psi($ global $), p($ width + depth $)$ & 515.51 & 1.39 & 0.3319 & 12 & 491.51 \\
\hline$\psi($ (river),$p($ width + depth) & 524.84 & 10.72 & 0.0031 & 6 & 512.84 \\
\hline$\psi($ season $), p($ width + depth) & 546.34 & 32.22 & 0 & 5 & 536.34 \\
\hline$\psi($ depth $), p($ width + depth $)$ & 552.99 & 38.87 & 0 & 5 & 542.99 \\
\hline$\psi($ depth + width $), p($ width + depth $)$ & 554.98 & 40.86 & 0 & 6 & 542.98 \\
\hline$\psi(),. p($ width + depth $)$ & 558.81 & 44.69 & 0 & 4 & 550.81 \\
\hline$\psi(),$.$p (width)$ & 559.32 & 45.2 & 0 & 3 & 553.32 \\
\hline$\psi(),. p($ season $)$ & 559.53 & 45.41 & 0 & 3 & 553.53 \\
\hline$\psi($ width $), p$ (width + depth) & 560.24 & 46.12 & 0 & 5 & 550.24 \\
\hline$\psi(),. p($ depth $)$ & 560.39 & 46.27 & 0 & 3 & 554.39 \\
\hline$\psi($ habitat), $p$ (width + depth) & 560.56 & 46.44 & 0 & 7 & 546.56 \\
\hline$\psi(),. p($ time $)$ & 561.21 & 47.09 & 0 & 4 & 553.21 \\
\hline$\psi(),. p()$. & 561.28 & 47.16 & 0 & 2 & 557.28 \\
\hline
\end{tabular}

Table 2. Estimates of untransformed coefficients $(\beta)( \pm \mathrm{SE})$ of habitat and seasonal covariate effects on occurrence of Ganges River dolphins Platanista gangetica gangetica derived from survey data from the Karnali, Sapta Koshi and Narayani Rivers, Nepal. Estimates are from the top-ranking model in which the covariate was supported; $\Sigma \omega_{i}$ is the cumulative weight of support for that covariate. Confidence intervals (CI) were calculated assuming a normal distribution. Bold indicates parameters significant for occupancy (at $p<0.05$ )

\begin{tabular}{|c|c|c|c|c|c|}
\hline \multirow{2}{*}{$\begin{array}{l}\text { Covariate } \\
\text { Substructure }\end{array}$} & \multirow[t]{2}{*}{$\beta$} & \multirow[t]{2}{*}{$\mathrm{SE}$} & \multicolumn{2}{|c|}{ CI (\%) } & \multirow[t]{2}{*}{$\Sigma \omega_{\mathrm{i}}$} \\
\hline & & & 2.5 & 97.5 & \\
\hline \multicolumn{6}{|c|}{ Detection parameters } \\
\hline River width & 0.35 & 0.20 & -0.05 & 0.74 & 1.000 \\
\hline River depth & 0.12 & 0.28 & -0.43 & 0.67 & 1.000 \\
\hline \multicolumn{6}{|c|}{ Site-use parameters } \\
\hline \multicolumn{6}{|l|}{ River } \\
\hline Karnali & 3.59 & 1.03 & 1.56 & 5.61 & 1.000 \\
\hline SaptaKoshi & 3.35 & 1.02 & 1.35 & 5.36 & 1.000 \\
\hline Narayani & -5.35 & 1.02 & -7.35 & -3.34 & 1.000 \\
\hline \multicolumn{6}{|l|}{ Season } \\
\hline Pre-monsoon & 1.13 & 0.32 & 0.50 & 1.76 & 0.997 \\
\hline \multicolumn{6}{|l|}{ Habitat } \\
\hline Deep pool & 1.23 & 0.55 & 0.15 & 2.30 & 0.332 \\
\hline Straight channel & 0.17 & 0.55 & -0.91 & 1.24 & 0.332 \\
\hline Confluence & 0.55 & 0.57 & -0.57 & 1.67 & 0.332 \\
\hline River width & -0.19 & 0.17 & -0.53 & 0.15 & 0.332 \\
\hline River depth & -0.15 & 0.19 & -0.53 & 0.23 & 0.332 \\
\hline
\end{tabular}

dance (Table 3). The suitable habitat/connectivity covariate also received support, but the $\beta$-coefficient estimates were highly variable, with CIs strongly overlapping 0 . We used the top-ranking model to estimate dolphin abundance across all surveyed segments of the 3 rivers (Table 4 ). Since the $\beta$-coefficients were not all significant, we also included the negative binomial constant model estimates and the maximum count observed per survey for conservative estimates of abundance. Since the preand post-monsoon seasons were independent, we provided seasonspecific estimates for all the segments, as well as a global abundance estimate for all of Nepal (Table 4). We estimate that 28 to 52 (95\% CI) of Ganges River dolphins are currently distributed among the 3 rivers in Nepal. Observed mean $( \pm \mathrm{SD})$ dolphin group size was $2.25 \pm$ 1.75, with the largest group size (6 dolphins in a single group) recorded in Sapta Koshiat. 
Table 3. Model selection statistics for all models with untransformed coefficients of habitat and seasonal covariate effects on abundance estimates for the Ganges River dolphin Platanista gangetica gangetica derived from $N$-mixture models applied to survey data from the Karnali, Sapta Koshi and Narayani Rivers, Nepal. $\Delta_{i}$ : Akaike's information criterion (AIC) difference; $\omega_{i}$ : Akaike weight; $K$ : number of model parameters. Entries in bold are significant in that confidence intervals exclude zero. Models follow a negative binomial distribution unless otherwise noted. (-) not applicable

\begin{tabular}{|c|c|c|c|c|c|c|c|c|}
\hline \multirow{2}{*}{ Model } & \multirow{2}{*}{$\Delta_{i}$} & \multirow{2}{*}{$\omega_{i}$} & \multirow[t]{2}{*}{$K$} & \multicolumn{4}{|c|}{ - Untransformed coefficients of covariates (SE) } & \multirow[b]{2}{*}{$\begin{array}{c}\text { Season } \\
\text { (post-monsoon }\end{array}$} \\
\hline & & & & Intercept & Karnali & Sapta Koshi & Habitat & \\
\hline River + habitat & 0.00 & 0.690 & 6 & $-10.53(18.88)$ & $1.99(0.77)$ & $3.13(0.76)$ & $10.56(18.87)$ & - \\
\hline Global & 1.65 & 0.300 & 7 & $-9.67(12.72)$ & $1.99(0.77)$ & $3.13(0.76)$ & $9.77(12.70)$ & $-0.15(0.25)$ \\
\hline Habitat & 11.83 & 0.002 & 4 & $-8.84(29.60)$ & - & - & $11.03(29.60)$ & - \\
\hline $\begin{array}{l}\text { Constant negative } \\
\text { binomial }\end{array}$ & 28.17 & 0.000 & 3 & $1.48(0.61)$ & - & - & - & - \\
\hline River & 29.77 & 0.000 & 5 & $-0.67(1.20)$ & $2.19(1.47)$ & $2.63(1.46)$ & - & - \\
\hline Post-monsoon & 30.16 & 0.000 & 4 & $-0.82(0.40)$ & - & - & - & $-0.15(1.14)$ \\
\hline Post-monsoon + river & 31.53 & 0.000 & 6 & $-0.58(1.22)$ & $2.34(1.52)$ & $2.84(1.54)$ & - & $-0.53(1.09)$ \\
\hline Constant Poisson & 103.57 & 0.000 & 2 & $1.16(0.143)$ & - & - & - & - \\
\hline
\end{tabular}

\section{DISCUSSION}

The Karnali and Sapta Koshi Rivers had higher occurrence probabilities and abundance estimates for GRDs than the Narayani River. Higher occurrence probabilities suggest that these 2 rivers are more vital to river dolphin conservation in Nepal than the Narayani. The northern sections of the Narayani are not favorable in terms of the ecological needs of the dolphins due to habitat fragmentation and high competition pressure from buffer zone communities (Choudhary et al. 2012). Our results also suggest that even though portions of the Narayani lie within the core area of Chitwan National Park, the variability of the water level (and hence deep pools) is largely dependent upon the barrage gates, limiting habitat suitability in that river segment (Smith et al. 1998, Smith \& Reeves 2000a). Seasonal flows characterize the rivers of Nepal (Chalise et al. 2003). Furthermore, during monsoon seasons, dolphins move into tributaries to reduce the risk from floods and floating debris, suggesting that vital tributaries are absent in the northern Narayani sections. Barrage management seems to be one of the most important factors for recovery of dolphin populations in the Nepalese sections of the river systems. Thus, successful river dolphin conservation requires effective water management in the rivers of the region (Smith et al. 1998).

The site-use models also revealed a strong relationship between dolphin habitat use and deep pools in those segments. River confluences have been suggested as high quality habitat for river dolphins in Asia (Timilsina et al. 2003) and South America (McGuire \& Winemiller 1998), yet our results suggested that dolphin occurrence was more probable in river segments with deep pools. Deep pools have also

Table 4. Abundance estimates for Ganges River dolphins Platanista gangetica gangetica derived from $N$-mixture models applied to survey data from the Karnali, Sapta Koshi and Narayani Rivers, Nepal. Included are maximum observation counts (Max obs), season-specific estimates (N-est) (with 2.5 and $97.5 \%$ confidence intervals, CI) from the top-ranking model, and the constant negative binomial model estimates (Constant NB) for comparison

\begin{tabular}{|c|c|c|c|c|c|c|c|c|c|c|}
\hline \multirow{3}{*}{$\begin{array}{l}\text { River } \\
\text { Segment }\end{array}$} & \multicolumn{5}{|c|}{ Pre-monsoon } & \multirow{3}{*}{$\begin{array}{c}\text { Max } \\
\text { obs }\end{array}$} & \multirow{3}{*}{$\begin{array}{l}\text { Po } \\
\text { N-est }\end{array}$} & \multicolumn{2}{|c|}{ st-monsoon } & \multirow{3}{*}{$\begin{array}{c}\text { Constant } \\
\text { NB }\end{array}$} \\
\hline & \multirow{2}{*}{$\begin{array}{l}\text { Max } \\
\text { obs }\end{array}$} & \multirow[t]{2}{*}{ N-est } & \multicolumn{2}{|c|}{ CI (\%) } & \multirow{2}{*}{$\begin{array}{c}\text { Constant } \\
\text { NB }\end{array}$} & & & \multicolumn{2}{|c|}{ CI (\%) } & \\
\hline & & & 2.5 & 97.5 & & & & 2.5 & 97.5 & \\
\hline \multicolumn{11}{|l|}{ Karnali } \\
\hline 1 & 0 & 0.00 & 0 & 0 & 0 & 0 & 0.00 & 0 & 0 & 0 \\
\hline 2 & 4 & 5.80 & 4 & 8 & 5 & 2 & 3.77 & 2 & 6 & 3 \\
\hline 3 & 8 & 11.49 & 9 & 14 & 11 & 5 & 9.23 & 7 & 12 & 8 \\
\hline \multicolumn{11}{|c|}{ Sapta Koshi } \\
\hline 1 & 0 & 0.00 & 0 & 0 & 0 & 0 & 0.00 & 0 & 0 & 0 \\
\hline 2 & 0 & 0.00 & 0 & 0 & 0 & 0 & 0.00 & 0 & 0 & 0 \\
\hline 3 & 14 & 22.96 & 19 & 27 & 20 & 14 & 24.37 & 21 & 28 & 21 \\
\hline \multicolumn{11}{|l|}{ Narayani } \\
\hline 1 & 0 & 0.00 & 0 & 0 & 0 & 0 & 0.00 & 0 & 0 & 0 \\
\hline 2 & 2 & 2.04 & 2 & 3 & 2 & 0 & 0.03 & 0 & 1 & 0 \\
\hline Total & 28 & 42.28 & 34 & 52 & 38 & 21 & 37.39 & 30 & 47 & 32 \\
\hline
\end{tabular}


been identified as preferred habitat by river dolphins and their fish prey in the upper stretches of the Ganges River in India (Bashir et al. 2010). The depth and width recorded in our investigation were lower than the observed threshold for dolphin survival during the post-monsoon period (Akbar et al. 2004, Smith et al. 2008) and, as a consequence, abundance was likely reduced compared to the pre-monsoon season. Akbar et al. (2004) did not observe any dolphins in river stretches with a depth of less than $\sim 1.5 \mathrm{~m}$, so the pre-monsoon season might be the most critical period for the dolphins in Nepal and other northern stretches of their range, particularly with climate change having the potential to affect water levels. Similarly, the drawdown of water levels in the Cinaruco River in Venezuela resulted in the abandonment of flooded Amazonian forests by botos Inia geoffrensis (Amazon River dolphins; McGuire \& Winemiller 1998). Our results reveal the importance of river morphology and seasonal ecology to dolphin occurrence and abundance and are therefore useful for the development of site-specific conservation actions throughout Nepal.

Although detection seems to be an issue for surveying river dolphins, the detection estimates from the occupancy models were encouraging. River width and depth both positively affected dolphin detection. This effect might be a result of dolphins surfacing more often in wide river segments because there is sufficient space for them to not feel threatened by the survey boats. It might also be a consequence of deep pools (depth) being a preferred habitat. Dolphin counts did, however, vary among the different surveys, suggesting a substantial detection bias. Other cetacean studies have also observed detection probabilities <1 (Shrestha 1989, Smith et al. 1994, Timilsina et al. 2003, WWF-Nepal 2006, Paudel et al. 2014) and it is appropriate and important to account for these biases when determining population estimates, particularly for rare and endangered species (Nicholson et al. 2012). We suggest that future surveys in an $\mathrm{N}$-mixture model framework might benefit from measuring additional detection covariates at the scale of the sites. The derived abundance estimates from our surveys are the first to account for such bias and robustly estimate the global population for Nepal, which is likely why our estimates are slightly higher than any previous surveys (e.g. 7 individuals, Smith 1993; 16 individuals, WWF-Nepal 2006). We estimate that we failed to detect between 6 and 24 dolphins during the surveys. This result is most likely a consequence of dolphins (1) travelling into tributaries and being temporarily unavailable for sampling,
(2) hiding amongst debris, or (3) failing to surface within sight of the observation crew. Similar behavior has been shown to occur in the botos of the Amazon, where sexual segregation occurs during seasonal floods (McGuire \& Winemiller 1998, Martin \& da Silva 2004). Our methodology provides a standardized protocol, and should be applied to future surveys monitoring the status of the Critically Endangered Nepalese dolphin population. Additionally, the use of visual-acoustic surveys (Akamatsu et al. 2001, Wang et al. 2006, Mellinger et al. 2007) might aid in more accurately estimating the population by accounting for missing individuals in visual surveys. This approach is appropriate for species that are rarely spotted because they spend long periods of time under water.

The 2 lower stretches of the Karnali River where dolphins were observed have low water speeds and adequate amounts of deep pool habitats. Additionally, $20 \mathrm{~km}$ below the India/Nepal border there is a barrage, which is a stronghold for dolphins because of conservation efforts made by the Indian Government. We detected 12 dolphins in the 2 southern sections and estimated there were likely 16 individuals in the entire section of the river within Nepal. In contrast, only 3 or 4 dolphins were observed in the Karnali River over a decade prior to our study. It is probable that the low detections from the 2003 study (Timilsina et al. 2003) were due to detection bias (which we accounted for), so it is difficult to determine if there was a significant change in abundance.

The Sapta Koshi River had the highest number of river dolphins and is likely the largest sub-population in the country. Khatri et al. (2010) observed 11 dolphins along the length of the Koshi River after a major flood in 2008. Similarly, Limbu \& Subba (2011) counted 11 dolphins in the Koshi River during the same time period. The maximum observed count (minimum known alive) in our surveys of Koshi was 14 individuals with detection bias-adjusted estimates ranging from 19 to 27 individuals $(95 \% \mathrm{CI})$. These numbers are encouraging because they suggest an increase in abundance in the Koshi since the flood of 2008. However, all of the individuals were counted in the southern section of the river (on the Nepal/India border) and none were detected in the northern 2 segments, which are north of a barrage that severely limits the distribution of the dolphins. Dams are known to serve as barriers to movement for river dolphins (Smith \& Smith 1998, Smith et al. 1998, Dudgeon 2005, Dudgeon et al. 2006). Furthermore, the southern extent of the Koshi population is connected to the Indian population so individuals can emigrate 
and disperse to India and possibly be lost from the Nepalese population. Even as the largest sub-population in Nepal, the dolphins of Sapta Koshi are not likely a genetically viable population without immigration from India and potential translocations of individuals (Smith et al. 1998, Zheng et al. 2005).

River geometry (and geomorphics) and development structures constructed at the India/Nepal border (developed in all river systems) pose the greatest threat towards the extinction of the river dolphin due to the dramatic changes in river flow characteristics (Paudel et al. 2014). Anthropogenic pressures such as the presence of fishing boats, stone quarries and motorboats used for local transportation along ghat areas (local transportation points across the rivers) are the other associated threats-all of which appear to be more localized, yet they are likely compounding effects in the decline of the GRD in Nepal. Changing the natural course of river systems (e.g Sapta Koshi and Geruwa to western flow in Karnali) with fluctuating depth profiles and fragmented deep pools greatly affects dolphin occurrence. Additionally, large numbers of local ghat areas (i.e. 4 ghats over the study stretch in Karnali, but not in Narayani or Sapta Koshi) are likely factors contributing to the decrease in the dolphin's distribution $(46 \mathrm{~km}$ in 1986; $32 \mathrm{~km}$ in this study; also see WWF-Nepal 2006) in Nepal.

Although our results reveal a severely limited river dolphin population with low abundance and fragmented sub-populations, our global estimate for all of Nepal ( $95 \%$ CI $=28$ to 52 individuals) is higher than the estimated population of 20 individuals in 2011 (Jnawali et al. 2011), likely due to our inclusion of adjustments for detection bias. We are somewhat encouraged that the population of dolphins in Nepal is likely larger than previously appreciated; however, we believe that it is imperative that these data are used to develop local and global recovery strategies for the management of this Critically Endangered species.

\section{CONCLUSIONS}

Our population estimates and details of habitat use are the first attempt in Nepal to generate detailed science-based information, and serve as an important baseline for conservation planning, further study, and comparison to other dolphins of the Ganges River watershed in Nepal. This small remaining population of river dolphins is at the brink of extinction due to river geometry and human developments at the Nepal/India border. Conservation inter- ventions (e.g. translocation in Sapta Koshi or extension of the Koshi Tappu Wildlife Reserve boundary; some artificial tributaries in southern sections of Narayani) are essential in Nepal's river systems, as are site-specific conservation action plans. The postmonsoon season is critical for dolphin survival in Nepal, therefore seasonal attention from the respective authorities is also important. Dolphins can be difficult to detect, so integration of additional technologies could enhance the accuracy and precision of estimates for the Nepalese population. Continued investigations of dolphin abundance and occupancy as well as their behaviors in relation to ecological components are strongly recommended to assess the population trend and risk of extinction of the dolphins of Nepal.

Acknowledgements. The authors thank Ocean Park Conservation Foundation, Hong Kong; the Rufford Foundation, UK; TAL-WWF, Hariyo Ban Program; IMATA, USA; and Chicago Zoological Society, USA, for financial support. Thanks to P. Basnet, M. Haiju, G. Tripathi, R. Acharya and P. Poudel for data collection and management. We are grateful to the anonymous reviewers for their constructive comments which greatly improved the manuscript. Thanks are also due to the Department of National Parks and Wildlife Conservation for granting permission for this study in Nepal.

\section{LITERATURE CITED}

Akaike H (1973) Information theory and an extension of the maximum likelihood principle. In: Petrov BN, Csaki F (eds) Proc $2^{\text {nd }}$ Int Symp Information Theory. Akadémia Kiadó, Budapest, p 267-281

Akamatsu T, Wang D, Wang K, Wei Z (2001) Comparison between visual and passive acoustic detection of finless porpoises in the Yangtze River, China. J Acoust Soc Am 109:1723-1727

Akbar M, Chaudhry AA, Arshed MJ (2004) Effect of water depth and river width on Indus dolphin population. Pak J Life Soc Sci 2:33-35

> Bashir T, Khan A, Gautam P, Behera SK (2010) Abundance and prey availability assessment of Ganges River dolphin (Platanista gangetica gangetica) in a stretch of upper Ganges River, India. Aquat Mamm 36:19-26

> Biswas SP, Boruah S (2000) Ecology of the river dolphin (Platanista gangetica gangetica) in the upper Brahmaputra. Hydrobiologia 430:97-111

Burnham KP, Anderson DR (2002) Model selection and multimodel inference: a practical information-theoretic approach. Springer, New York, NY

Chalise SR, Kansakar SR, Rees G, Croker K, Zaidman M (2003) Management of water resources and low flow estimation for the Himalayan basins of Nepal. J Hydrol (Amst) 282:25-35

Chaudhary S (2007) Status of, and threats to, the Ganges River dolphin (Platanista gangetica gangetica) in the Koshi River, Nepal. MSc thesis, University of Klagenfurt 
Choudhary S, Dey S, Dey S, Sagar V, Nair T, Kelkar N (2012) River dolphin distribution in regulated river systems: implications for dry-season flow regimes in the Gangetic basin. Aquat Conserv 22:11-25

> Cove MV, Pardo Vargas LE, de la Cruz JC, Spínola RM, Jackson VL, Saénz JC, Chassot O (2014) Factors influencing the occurrence of the Endangered Baird's tapir Tapirus bairdii: potential flagship species for a Costa Rican biological corridor. Oryx 48:402-409

Dudgeon D (2005) River rehabilitation for conservation of fish biodiversity in monsoonal Asia. Ecol Soc 10:art15

> Dudgeon D, Arthington AH, Gessner MO, Kawabata ZI and others (2006) Freshwater biodiversity: importance, threats, status and conservation challenges. Biol Rev Camb Philos Soc 81:163-182

Fiske I, Chandler R (2011) Unmarked: an R package for fitting hierarchical models of wildlife occurrence and abundance. J Stat Softw 43:1-23

Hines J (2012) PRESENCE v.8.0. US Geological Survey, Patuxent Wildlife Research Center, Patuxent, MD

Janawali SR, Bhuju UR (2000) The Ganges River dolphin: current status and conservation threats. Presentation at the WWF regional workshop on the south Asian river dolphin, 4-7 November 2000, Taunsa

Jnawali SR, Baral HS, Lee S Acharya KP and others (2011) The status of Nepal mammals: the National Red List series. Department of National Parks and Wildlife Conservation, Kathmandu

Kelkar N, Krishnaswamy J, Choudhary S, Sutaria D (2010) Coexistence of fisheries with river dolphin conservation. Conserv Biol 24:1130-1140

Khatri TB, Shah DN, Mishra N (2010) Post-flood status of the endangered Ganges River dolphin Platanista gangetica gangetica (Cetartiodactyla: Platanistidae) in the Koshi River, Nepal. J Threat Taxa 2:1365-1371

Leatherwood S, Reeves RR (1994) River dolphins: a review of activities and plans of the cetacean specialist group. Aquat Mamm 20:137-154

Leatherwood S, Reeves RR, Wursig B, Shearn D (2000) Habitat preferences of river dolphins in the Peruvian Amazon. In: Reeves RR, Smith BD, Kasuya T (eds) Biology and conservation of freshwater cetaceans in Asia. Occasional Paper No. 23, IUCN Species Survival Commission, Gland, p 131-143

Limbu KP, Subba BR (2011) Status of key faunal species in Koshi Tappu Wildlife Reserve after Koshi flood disaster 2008. Nepalese J Biosci 1:41-54

> Mackenzie DI, Nichol JD, Lachman GB, Droege S, Royle JA, Lanftimn CA (2002) Estimating site occupancy rates when detection probabilities are less than one. Ecology 83:2248-2255

Martin AR, da Silva VMF (2004) River dolphins and flooded forest: seasonal habitat use and sexual segregation of botos (Inia geoffrensis) in an extreme cetacean environment. J Zool 263:295-305

> McGuire TL, Winemiller KO (1998) Occurrence patterns, habitat associations, and potential prey of the river dolphin, Inia geoffrensis, in the Cinaruco River, Venezuela. Biotropica 30:625-638

Mellinger DK, Stafford KM, Moore S, Dziak RP, Matsumoto $\mathrm{H}$ (2007) Fixed passive acoustic observation methods for cetaceans. Oceanography 20:36-45

Nicholson K, Bejder L, Allen SJ, Krützen M, Pollock KH (2012) Abundance, survival and temporary emigration of bottlenose dolphins (Tursiops sp.) off Useless Loop in the western gulf of Shark Bay, Western Australia. Mar Freshw Res 63:1059-1068

Paudel S (2012) Factor assessment of Ganges River dolphins movement in Karnali River system of Nepal. MSc thesis, Tribhuvan University, Kathmandu

Paudel S, Timilsina YP, Lewis J, Ingersoll T, Jnawali SR (2014) Population status and habitat occupancy of endangered river dolphins in the Karnali River system of Nepal during low water season. Mar Mamm Sci 31: 707-719

Richman NI, Gibbons JM, Turvey ST, Akamatsu T and others (2014) To see or not to see: investigating detectability of Ganges River dolphins using a combined visualacoustic survey. PLoS ONE 9:e96811

Royle JA, Dorazio RM (2008) Hierarchical modeling and inference in ecology: the analysis of data from populations, metapopulations and communities. Academic Press, New York, NY

Shostell JM, García MR (2010) An introduction to river dolphin species. In: Ruiz-Garcia M, Shostell JM (eds) Biology, evolution and conservation of river dolphins within South America and Asia. NOVA Science Publishers, New York, NY, p 1-28

Shrestha TK (1989) Biology, status and conservation of the Ganges River dolphin in Nepal. In: Perrin WF, Brownell RL Jr, Kaiya Z, Jiankang L (eds) Biology and conservation of the river dolphins. Occasional Paper No. 3, IUCN Species Survival Commission, Gland, p 70-76

Smith AM, Smith BD (1998) Review of status and threats to river cetaceans and recommendations for their conservation. Environ Rev 6:189-206

Smith BD (1993) 1990 status and conservation of the Ganges River dolphins (Platanista gangetica) in Karnali River, Nepal. Biol Conserv 66:159-169

Smith BD, Reeves RR (2000a) Report of the workshop on the effects of water development on river cetaceans, 26-28 February 1997, Rajendrapur, Bangladesh. In: Reeves RR, Smith BDE, Kasuya T (eds) Biology and conservation of freshwater cetaceans in Asia. Occasional Paper No. 23, IUCN Species Survival Commission, Gland, p 15-22

Smith BD, Reeves RR (2000b) Survey methods for population assessment of Asian River dolphins. In: Reeves RR, Smith BDE, Kasuya T (eds) Biology and conservation of freshwater cetaceans in Asia. Occasional Paper No. 23, IUCN Species Survival Commission, Gland, p 97-115

Smith BD, Sinha RK, Regmi U (1994) Status of Ganges River dolphins (Platanista gangetica) in the Karnali, Mahakali, Narayani and Sapta Kosi Rivers of Nepal and India in 1993. Mar Mamm Sci 10:368-375

Smith BD, Haque AA, Hossain MS, Khan A (1998) River dolphins in Bangladesh: conservation and the effects of water development. Environ Manage 22:323-335

Smith BD, Braulik G, Strindberg S, Ahmed B, Mansur R (2006) Abundance of Irrawaddy dolphins (Orcaella brevirostris) and Ganges River dolphins (Platanista gangetica gangetica) estimated using concurrent counts made by independent teams in waterways of the Sundarbans mangrove forest in Bangladesh. Mar Mamm Sci 22: $527-547$

Smith BD, Ahmed B, Nowgli RM, Strindberg S (2008) Species occurrence and distributional ecology of nearshore cetaceans in the Bay of Bengal, Bangladesh, with abundance estimates for Irrawaddy dolphins Orcaella brevirostris and finless porpoises Neophocaena phocaenoides. J Cetacean Res Manag 10:45-58 
R Development Core Team (2013) R: a language and environment for statistical computing. R foundation for statistical computing, Vienna

Timilsina N, Tamang B, Baral N (2003) Status and conservation of Gangetic dolphin in the Karnali River, Nepal. Tigerpaper 30:8-10

Wakid A (2007) Report on the initiatives to involve the major stakeholders of Assam in the conservation of Gangetic dolphin. Gangetic Dolphin Research and Conservation Programme, Aaranyak, Aasam

Wang K, Wang D, Akamatsu T, Fujita K, Shiraki R (2006)

Editorial responsibility: Kartik Shanker, Bangalore, India
Estimated detection distance of a Baiji's (Chinese river dolphin, Lipotes vexillifer) whistles using a passive acoustic survey method. J Acoust Soc Am 120:1361-1365

WWF-Nepal (2006) Status, distribution and conservation threats of Ganges River dolphin in Karnali River, Nepal. World Wildlife Fund-Nepal, Kathmandu

Zheng JS, Xia JH, He SP, Wang D (2005) Population genetic structure of the Yangtze finless porpoise ( Neophocaena phocaenoides asiaeorientalis): implications for management and conservation. Biochem Genet 43: $307-320$

Submitted: February 12, 2015; Accepted: September 24, 2015 Proofs received from author(s): November 2, 2015 